University of Nebraska - Lincoln

DigitalCommons@University of Nebraska - Lincoln

\title{
Estrogenic Compounds Downstream from Three Small Cities in Eastern Nebraska: Occurrence and Biological Effect
}

\author{
Marlo K. Sellin \\ University of Nebraska Medical Center, Omaha \\ Daniel D. Snow \\ University of Nebraska at Lincoln, dsnow1@unl.edu \\ Debbie L. Akerly \\ University of Nebraska- Omaha, \\ Alan S. Kolok \\ University of Nebraska-Omaha, akolok@mail.unomaha.edu
}

Follow this and additional works at: https://digitalcommons.unl.edu/watercenterpubs

Part of the Water Resource Management Commons

Sellin, Marlo K.; Snow, Daniel D.; Akerly, Debbie L.; and Kolok, Alan S., "Estrogenic Compounds Downstream from Three Small Cities in Eastern Nebraska: Occurrence and Biological Effect" (2009). Faculty Publications from The Water Center. 17.

https://digitalcommons.unl.edu/watercenterpubs/17

This Article is brought to you for free and open access by the Water Center, The at DigitalCommons@University of Nebraska - Lincoln. It has been accepted for inclusion in Faculty Publications from The Water Center by an authorized administrator of DigitalCommons@University of Nebraska - Lincoln. 
Published in Journal of the American Water Resources Association 45:1 (2009), pp. 14-21; doi: 10.1111/j.1752-1688.2008.00285.x Copyright (c) 2009 American Water Resources Association; published by Wiley-Blackwell. Used by permission.

Submitted November 30, 2007; accepted March 21, 2008; published online January 27, 2009.

\title{
Estrogenic Compounds Downstream from Three Small Cities in Eastern Nebraska: Occurrence and Biological Effect
}

\author{
Marlo K. Sellin, ${ }^{1}$ Daniel D. Snow, ${ }^{2}$ Debbie L. Akerly, ${ }^{3}$ and Alan S. Kolok ${ }^{3}$ \\ 1 Center for Environmental Health and Toxicology, University of Nebraska Medical Center, Omaha, Nebraska 68198-6805; \\ 2 Water Sciences Laboratory, University of Nebraska-Lincoln, Lincoln, Nebraska 68583-0844; and \\ 3 Department of Biology, University of Nebraska at Omaha, Omaha, Nebraska 68182-0040. \\ Corresponding author - M. K. Sellin, msellin@mail.unomaha.edu
}

\begin{abstract}
Recent studies have detected estrogenic compounds in surface waters in North America and Europe. Furthermore, the presence of estrogenic compounds in surface waters has been attributed, in some cases, to the discharge of wastewater treatment plant (WWTP) effluent. The primary objective of the current study was to determine if WWTP effluent contributes estrogens to the surface waters of Nebraska. A second objective of this study was to determine if estrogens were found in concentrations sufficient enough to manifest feminizing effects on fish. These objectives were satisfied by deploying polar organic chemical integrative samplers (POCIS) and caged fathead minnows at eight field sites. Deployment sites included: three reference sites (Pawnee Creek, the Little Blue River, and the Middle Loup River), two sites upstream of the WWTPs at Grand Island and Columbus, and three sites downstream of the WWTPs at Grand Island, Columbus, and Hastings. Following the seven day deployments, POCIS extracts were analyzed for estrone, $17 \beta$-estradiol, estriol and 17a-ethinylestradiol using liquid chromatography tandem mass spectrometry (LC/MS/MS). 17 $\beta$-estradiol was detected in POCIS from six of the eight field sites with the greatest quantities recovered in POCIS deployed downstream from the Grand Island and Hastings WWTPs. Estrone was detected only in the POCIS deployed downstream from the Grand Island and Hastings WWTPs. Estrogenic effects were detected in caged minnows analyzed for the hepatic mRNA expression of two estrogen-responsive genes, vitellogenin (vg1) and estrogen receptor a (ERa). Fish deployed at the site where the greatest quantities of estrogens were recovered (Hastings) had significantly higher expression of both vg1 and ERa than fish deployed at any of the other sites. These results confirm that WWTP effluent contributes biologically significant levels of estrogens to Nebraska surface waters.
\end{abstract}

Keywords: wastewater treatment, environmental estrogens, gene expression, caged fish, environmental monitoring, endocrine disrupting compounds, POCIS

\section{Introduction}

Steroid hormones, such as estrogens, regulate several biological processes including growth, development, and reproduction. In fish, as well as other aquatic vertebrates, low levels (ng/l range) of waterborne estrogens lead to a suite of adverse effects including the feminization of males (Panter et al., 1998; Balch et al., 2004; Brion et al., 2004), impaired reproduction (Kramer et al., 1998; Shioda and Wakabayashi, 
2000; Brion et al., 2004; Imai et al., 2005), and abnormal sexual development (Hartley et al., 1998; Hirai et al., 2006; Holbech et al., 2006). Thus, the presence of estrogens in the aquatic environment, even at low concentrations, is likely to pose a significant threat to the health of aquatic organisms.

Several recent studies have detected estrogenic compounds in surface water (Goodbred et al., 1997; Kolpin et al., 2002; Soto et al., 2004; Vermeirssen et al., 2005; Lee and Rasmussen, 2006; Kolok et al., 2007). Wastewater treatment plant (WWTP) discharge has been identified as a major source of these estrogenic compounds (Williams et al., 2003; Aerni et al., 2004; Lee and Rasmussen, 2006). Domestic sewage entering WWTPs has been found to contain $17 \beta$-estradiol $\left(E_{2}\right)$, estrone $\left(E_{1}\right)$, estriol $\left(\mathrm{E}_{3}\right)$, and the synthetic estrogen, 17a-ethinylestradiol ( $\left.\mathrm{EE}_{2}\right)$ (Baronti et al., 2000; Carballa et al., 2004). Treatment processes employed by WWTPs are effective in removing a portion of the estrogens in sewage (Baronti et al., 2000; Carballa et al., 2004); however, effluent from several WWTPs has been shown to contain low, yet biologically active, concentrations of estrogenic compounds (Baronti et al., 2000; Johnson and Sumpter, 2001; Carballa et al., 2004).

As concern regarding the presence of estrogens in the aquatic environment has grown, several biomonitoring tools have emerged. In this study, two biomonitoring tools were employed-polar organic chemical integrative samplers (POCIS) and caged fish. POCIS are ideal for determining the time-weighted concentrations of hydrophilic contaminants in environments where the concentration of the contaminants can vary considerably over time (Alvarez et al., 2004, 2005; Petty et al., 2004; Vermeirssen et al., 2005; Matthiessen et al., 2006; Kolok et al., 2007). In addition to POCIS, caged fish can be used to assess water quality by measuring concentrations of xenobiotics in tissues (Gallassi et al., 1996; Otto et al., 1996) or inappropriate mRNA or protein expression (Sheahan et al., 2002; Roberts et al., 2005; Vermeirssen et al., 2005; Burki et al., 2006). In this study, hepatic mRNA expression of two estrogen-responsive genes, vitellogenin (vg1) and estrogen receptor a (ERa), in caged fathead minnows (Pimephales promelas) was measured.

The primary objective of this study was to determine, using POCIS, if WWTP effluent contributes estrogens to surface waters of Nebraska. A second objective of this study, using the relative mRNA expression of two estrogen-responsive genes in caged mature male and immature female minnows, was to determine if these compounds were found in quantities sufficient enough to manifest feminizing effects in fish.

\section{Methods}

\section{Field Sites}

During the late summer of 2006, laboratory-raised mature male and immature female fathead minnows and POCIS were deployed at eight different locations in Nebraska (Table 1, Figure 1). Caged fish and POCIS were deployed downstream ( $<5 \mathrm{~km}$ from the outflow) from the WWTPs of three small Nebraska cities: Grand Island (population 41,000), Columbus (population 20,514), and Hastings (population 22,956). Fish and POCIS were also deployed upstream of the Grand Island and Columbus WWTPs. The Hastings WWTP was located at the headwaters of the west fork of the Big Blue River; therefore, deployment above the discharge was not possible. Field

Table 1. Water temperature and $\mathrm{pH}$ at the eight field sites during the summer of 2006.

\begin{tabular}{llcl}
\hline & $\begin{array}{c}\text { Days } \\
\text { Deployment/Site }\end{array}$ & & \\
\hline Deployed & Temperature & $\mathrm{pH}$ \\
\hline Grand Island WWTP (u) & 7 & $22.5(1.0)$ & $7.0(0.1)$ \\
Grand Island WWTP (d) & $27^{*}$ & - & - \\
Hastings WWTP (d) & 7 & $23.4(1.4)$ & $7.6(0.1)$ \\
Little Blue River & 7 & $23.7(1.7)$ & $7.8(0.04)$ \\
Pawnee Creek & 7 & $21.4(3.3)$ & $7.6(0.7)$ \\
Deployment 2 (September 14) & & & \\
Columbus WWTP (u) & 7 & $16.8(2.6)$ & $7.9(0.1)$ \\
Columbus WWTP (d) & 7 & $17.1(2.4)$ & $7.9(0.1)$ \\
$\quad$ Middle Loup River & 7 & $19.2(4.9)$ & $8.1(0.1)$ \\
Deployment 3 (September 21) & & & \\
Grand Island WWTP (d) & 7 & $23.9(0.4)$ & $7.0(0.1)$ \\
\hline
\end{tabular}

(d) = downstream; $(\mathrm{u})=$ upstream.

Water quality values are means $( \pm \mathrm{SE})$ of those taken on the first and last day of the deployment.

* POCIS and fish were initially lost; however, POCIS and empty minnow cages were recovered during a subsequent deployment.

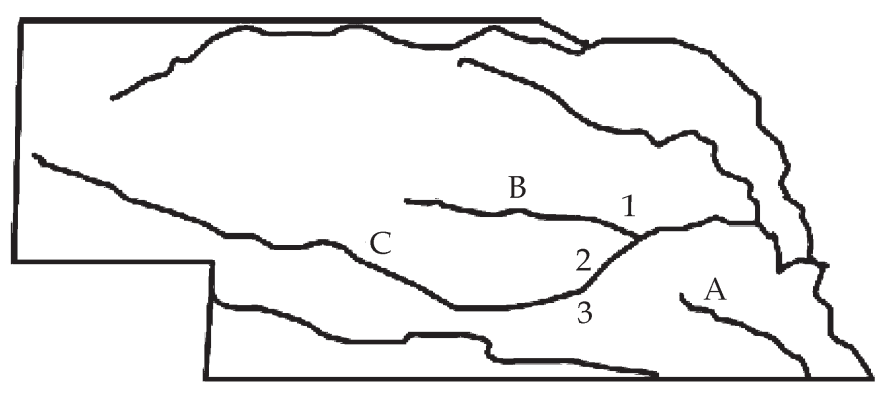

Figure 1. The location of the six deployment sites throughout the state of Nebraska. $1=$ Columbus Wastewater Treatment Plant, 2 = Grand Island Wastewater Treatment Plant, 3 = Hast ings Wastewater Treatment Plant, $\mathrm{A}=$ Little Blue River reference site, B = Loup River reference site, C = Pawnee Creek reference site. 
deployment of the fish and POCIS also occurred at three reference locations: Pawnee Creek, NW of Brady, Nebraska; the Little Blue River, NW of Deweese, Nebraska; and the Middle Loup River, W of Loup City, Nebraska. These reference sites were unlikely to be impacted by WWTP effluent.

After each deployment, minnows were returned to the laboratory measured for body mass, liver mass, and gonad mass. Gross observation of the gonads was used to confirm the sex of each minnow. Liver-somatic (LSI) and gonadosomatic (GSI) indices were generated by dividing the mass of the tissues into the body mass of the fish then multiplying by 100 . Immediately upon dissection, livers were snap frozen in liquid nitrogen and stored in a $-80^{\circ} \mathrm{C}$ freezer until analysis.

\section{POCIS Deployment and Analysis of Estrogenic Compounds}

Processing and extraction of the POCIS followed procedures described by Alvarez et al. (2004) and Kolok et al. (2007). Each individual POCIS was removed from its deployment canister, rinsed with water to remove any debris and opened. The contents of the POCIS were quantitatively transferred using high purity methanol into silane-treated amber glass scintillation vials and stored at $-20^{\circ} \mathrm{C}$ until the resin could be extracted. During extraction, resin and methanol were transferred to silanized glass chromatography columns for elution, and target compounds eluted with $50 \mathrm{ml}$ of 1:1:8 methanol: toluene:dichloromethane. Labeled internal standards (d2-estradiol and d5-testosterone) are added to the eluate and used for quantification. Extracts were evaporated under nitrogen to approximately $1 \mathrm{ml}$, and quantitatively transferred to autosampler vials for analysis using electrospray ionization liquid chromatographytandem mass spectrometry (LC/MS/MS). Because ion suppression was observed in extracts from some sites, indicated by low or no responses for the internal standards, these extracts were further purified using Florisil column clean-up.

Clean-up of wastewater extracts using Florisil for steroid hormone analysis has been described by Ingrand et al. (2003), Esperanza et al. (2006), and Hu et al. (2005). Yamamoto et al. (2006) used Florisil cartridges for clean up of surface water extracts for LC/MS/MS analysis of estrogens. Using this method, the POCIS extracts for this study were evaporated to dryness, redissolved in $1 \mathrm{ml}$ of 1:1 hexane:methylene chloride and transferred to $500 \mathrm{mg}$ Florisil cartridges (Supelclean ENVI-Florisil). Target compounds were eluted from the Florisil using $7 \mathrm{ml}$ 1:1 hexane:methylene chloride, evaporated to dryness un- der nitrogen and then redissolved in 1:1 methanol:water for LC/MS/MS analysis. Recovery through the clean-up procedure was evaluated by analysis of eight replicates fortified with analytes and internal standards.

Purified POCIS extracts were analyzed using a Waters 2695 quaternary pump and autosampler connected to a Micromass Quattro Micro triple-quadrupole mass spectrometer operated in both positive and negative modes. Detection and quantification of estrogenic compounds utilized multiple reaction monitoring (MRM) with argon collision gas during two separate runs. A Phenomenex Luna C18 column $(250 \times 2.1 \mathrm{~mm}, 5 \mu \mathrm{m}$, $50^{\circ} \mathrm{C}$ ) was used for separation at a flow rate of $0.2 \mathrm{ml} /$ min with each ionization mode using slightly different gradients of methanol in water or formic acid. The gradient in positive ionization mode varied from $40 \%$ methanol, $60 \%$ water, $0.1 \%$ formic acid for the first $10 \mathrm{~min}$ to $90 \%$ methanol, $10 \%$ water, $0.1 \%$ formic acid to $18 \mathrm{~min}$. The gradient in negative ionization mode used $20 \%$ methanol, $80 \%$ water for the first $3 \mathrm{~min}$ followed by $95 \%$ methanol, 5\% water for the next $15 \mathrm{~min}$. Both runs returned to initial solvent conditions for the last 10-12 $\mathrm{min}$ of the gradient.

Electrospray ionization and mass spectrometer parameters are: capillary $3.5 \mathrm{kV}$, extractor $2 \mathrm{~V}$, RF lens $0.2 \mathrm{~V}$ (neg) $0.7 \mathrm{~V}$ (pos), source temp $70^{\circ} \mathrm{C}$, desolvation temperature $425^{\circ} \mathrm{C}$, cone gas flow at $120 \mathrm{l} / \mathrm{h}$, and desolvation gas flow at $650 \mathrm{l} / \mathrm{h}$. Details of compound retention times, ionization modes, and MRM transitions are listed in Table 2. Using the Florisil clean up, analyte recoveries ranged from $75 \%$ for $17 a-e$ thinylestradiol to $115 \%$ for $E_{1}$ at $5.0 \mathrm{ng}$. Based on the variability of the lowest standard $(5 \mathrm{pg} / \mathrm{\mu l})$, the estimated detection limits are near $100 \mathrm{pg}$ on-column, corresponding to $1.0 \mathrm{ng}$ recovered from the POCIS.

\section{Gene Expression Analysis}

Gene expression analysis was conducted using previously published protocols (Kolok et al., 2007). Total

Table 2. Instrumental conditions for LC/MS/MS analysis of caffeine and estrogenic compounds in POCIS extracts.

\begin{tabular}{lcll}
\hline Compound & $\begin{array}{c}\text { Retention } \\
\text { Time (min) }\end{array}$ & $\begin{array}{c}\text { Ionization } \\
\text { Mode }\end{array}$ & $\begin{array}{c}\text { Mass } \\
\text { Transition }\end{array}$ \\
\hline Caffeine & 4.78 & Positive & 195.05 to $>138.05$ \\
Estriol & 11.33 & Negative & 287.15 to $>145.15$ \\
17a-ethinylestradiol & 12.24 & Negative & 295.15 to $>145.15$ \\
17 $\beta$-estradiol - d2 & 12.34 & Negative & 273.15 to $>147.15$ \\
17 $\beta$-estradiol & 12.34 & Negative & 271.15 to $>145.15$ \\
Estrone & 12.44 & Negative & 269.15 to $>145.15$ \\
\hline
\end{tabular}


RNA was isolated from each liver sample using the SV Total RNA Isolation System (Promega Corp., Madison, Wisconsin). Samples were quantified spectrophotometrically at 260 and $280 \mathrm{~nm}$, and only samples with absorbance $_{260}$ to absorbance 280 ratios greater than 1.7 were used in the subsequent analyses. First-strand cDNA was synthesized from $1 \mu \mathrm{g}$ total RNA in $20 \mu \mathrm{l}$ of reaction using an iScript cDNA Synthesis Kit (Bio-Rad Inc., Hercules, California). Real-time PCR reactions were performed using a Bio-Rad iCycler equipped with a real-time PCR detection system (MyiQ) managed by Optical System Software version 1.0. The reactions were conducted using iQ SYBR-Green supermix (Bio-Rad) as per the manufacturer's protocol. Data were quantified by the standard curve method using series diluted cDNA samples as a standard. The expression of each target gene mRNA was normalized by the expression of ribosomal protein L8 mRNA, and is expressed in relative terms. The QPCR in this study focused on two estrogen-responsive genes: vg1 and ERa. Primers for fathead minnow L8, vg1, and ERa have been published previously (Kolok et al., 2007).

Hepatic mRNA expression was evaluated for five fish of each sex from each group. Fish were chosen for analysis based on their body mass, GSI, and LSI. Outliers were removed from consideration and analysis was conducted on individuals chosen randomly from the remaining fish from each treatment group.

\section{Statistical Analysis}

Differences in body mass, organ indices, and hepatic mRNA expression were tested for using single factor analysis of variance (ANOVA, Statview 5.0) followed by Newman-Kuels multiple comparison tests. Statistical significance was assumed at $p \leq 0.05$.

\section{Results}

\section{Polar Organic Chemical Integrative Samples}

POCIS were analyzed in triplicate from each site. $E_{3}$ and the synthetic estrogen, $\mathrm{EE}_{2}$, were not detected in the POCIS deployed at any of the eight field sites (Table 3). In contrast, $17 \beta-\mathrm{E}_{2}$ was detected at six of the eight field sites, with the largest quantities recovered in POCIS downstream of the Grand Island and Hastings WWTPs. $\mathrm{E}_{1}$ was only detected in POCIS deployed downstream of the Grand Island and Hastings WWTPs, with the POCIS from Hastings containing nearly 10 times more $\mathrm{E}_{1}$ than that found in the POCIS from Grand Island. Determination of estrogen equivalents (Table 3 ) revealed that POCIS deployed downstream from the Hastings WWTP contained nearly twice the estrogen equivalent mass as the POCIS deployed downstream from the Grand Island WWTP.

\section{Body Mass and Organ Indices}

The average male body mass of each group ranged from 1.6 to $2.3 \mathrm{~g}$ and no significant differences between any of the groups were detected (ANOVA, $p=0.13$ ). Male LSI ranged from 1.2 to 2.2 and significant differences were detected (ANOVA, $p=0.047$ ); however, post hoc multiple comparisons tests did not reveal which groups differed from each other. Average male GSI ranged from 0.6 to 1.9, with no significant differences detected between any of the groups (ANOVA, $p$ $=0.096$ ).

Average female body mass ranged from 1.0 to $1.3 \mathrm{~g}$ with no differences detected between any of the groups (ANOVA, $p=0.055$ ). Female LSI ranged from 1.3 to 3.0

Table 3. Quantities of caffeine and estrogenic compounds (expressed in ng; mean \pm standard error, $n=3$ ) recovered from all POCIS deployed at eight sites throughout Nebraska during the summer of 2006.

\begin{tabular}{|c|c|c|c|c|c|c|c|c|}
\hline \multirow[b]{2}{*}{ Compound } & \multirow{2}{*}{$\begin{array}{c}\text { Pawnee } \\
\text { Creek }\end{array}$} & \multirow{2}{*}{$\begin{array}{c}\text { Middle } \\
\text { Loup } \\
\text { River }\end{array}$} & \multirow{2}{*}{$\begin{array}{l}\text { Little } \\
\text { Blue } \\
\text { River }\end{array}$} & \multicolumn{2}{|c|}{ Columbus } & \multicolumn{2}{|c|}{ Grand Island } & \multirow{2}{*}{$\frac{\text { Hastings }}{\text { Downstream }}$} \\
\hline & & & & Upstream & Downstream & Upstream & Downstream* & \\
\hline Caffeine & $2.5(0.3)$ & $2.1(0.4)$ & $3.4(0.9)$ & $13.6(0.4)$ & $11.8(6.6)$ & $29.7(6.0)$ & ND & $2834(614)$ \\
\hline 17a-ethinylestradiol & ND & ND & ND & ND & ND & ND & ND & ND \\
\hline Estriol & ND & ND & ND & ND & ND & ND & ND & ND \\
\hline $17 \beta$-estradiol & $1.9(2.1)$ & $1.5(0.9)$ & ND & ND & $1.3(1.1)$ & $3.5(0.6)$ & $12.2(4.1)$ & $14.5(5.4)$ \\
\hline Estrone & ND & ND & ND & ND & ND & ND & $2.6(1.3)$ & $22.9(5.0)$ \\
\hline Estrogen equivalents** & 1.9 & 1.5 & - & - & 1.3 & 3.5 & 13.1 & 22.7 \\
\hline
\end{tabular}






Figure 2. Relative Hepatic Vitellogenin (top panel) and Estrogen Receptor a (bottom panel) mRNA expression of males deployed at eight sites throughout Nebraska during the summer of 2006. $u=$ upstream, $d=$ downstream, * denotes significant differences between groups.

and significant differences between the groups were detected (ANOVA, $p<0.001$ ). Specifically, females deployed downstream from the Hastings and Grand Island WWTPs had significantly higher LSIs than females deployed upstream and downstream of the Columbus WWTP, at the Little Blue River and at the Middle Loup River. No other differences in female LSI between the groups were detected. Female GSI ranged from 1.7 to 4.5; however, there were no significant differences between any of the groups (ANOVA, $p=0.42$ ).

\section{Gene Expression}

Male hepatic vg1 and ERa mRNA expression was significantly higher in minnows deployed downstream of the Hastings WWTP relative to minnows deployed at any of the other sites (Figure 2) (ANOVA, $p<0.001$ in both cases). Likewise, females deployed downstream of the Hastings WWTP had significantly higher hepatic vg1 and ERa mRNA expression relative to minnows deployed at any of the other sites (Figure 3) (ANOVA, $p$ $<0.001$ in both cases).

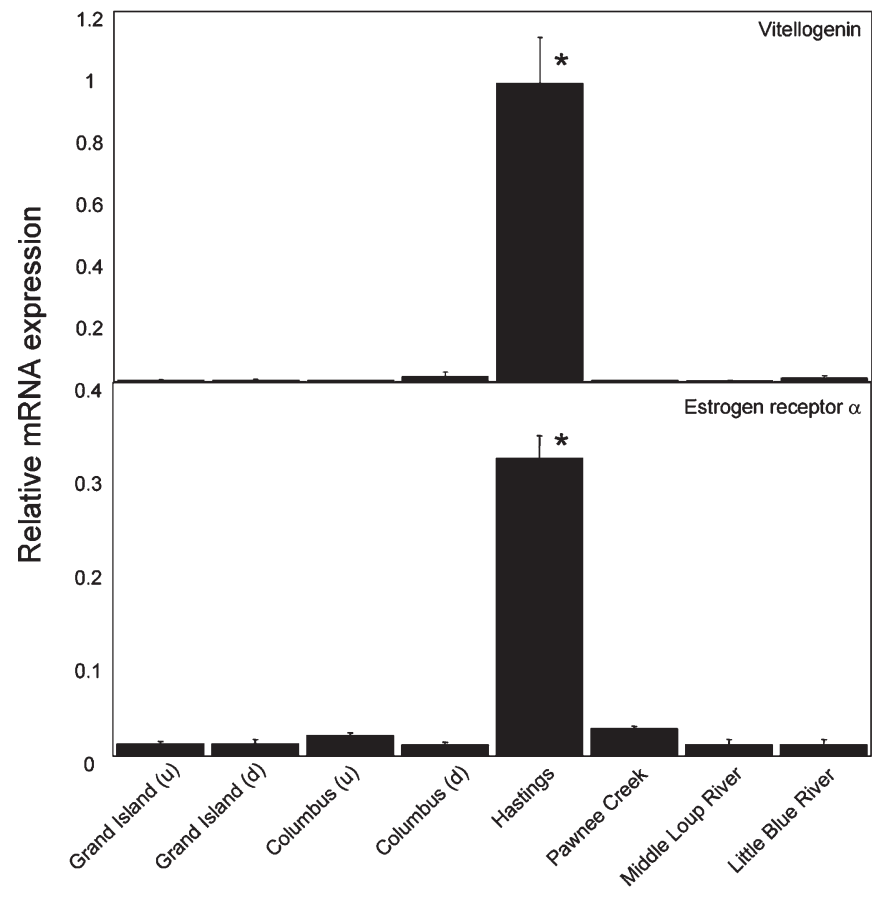

Figure 3. Relative Hepatic Vitellogenin (top panel) and Estrogen Receptor a (bottom panel) mRNA expression of females deployed at eight sites throughout Nebraska during the summer of 2006. $\mathrm{u}=$ upstream, $\mathrm{d}=$ downstream, * denotes significant differences between groups.

\section{Discussion}

The primary objective of this study was to determine, using POCIS, if WWTPs contribute biologically significant levels of estrogens to surface waters in $\mathrm{Ne}-$ braska. Results from this study indicate that estrogens, primarily $E_{1}$ and $E_{2}$, are found in the surface waters of Nebraska and that the greatest quantities of these compounds are found downstream from WWTPs.

A second objective of this study, using the relative mRNA expression of two estrogen-responsive genes in caged minnows, was to determine if these compounds were found in concentrations sufficient enough to manifest feminizing effects on caged fathead minnows. Minnows caged downstream of the Hastings WWTP had significantly higher hepatic vg1 and ERa expression than minnows caged at any of the other sites indicating the feminization of fish deployed at this site. These results were consistent with those from the POCIS, as the POCIS extracts from this site contained the greatest quantity of estrogen equivalents. 


\section{Polar Organic Chemical Integrative Samples}

Analysis of estrogenic compounds in POCIS revealed either undetectable or quantities near detection limits of estrogenic compounds at the three reference sites (the Little Blue River, Pawnee Creek, and the Middle Loup River) and at the two sites upstream of the WWTPs (Grand Island and Columbus). POCIS deployed downstream of the Columbus WWTP contained small quantities of $\mathrm{E}_{2}$, similar to those found at the reference sites, suggesting that the WWTP discharge is not likely contributing to the estrogenic load downstream of the Columbus WWTP. In contrast, significant levels of estrogens were recovered from POCIS deployed downstream of the Grand Island and Hastings WTTPs compared to POCIS deployed at the reference sites, indicating that the effluent from these WWTPs was the source of these estrogens. Caffeine levels recovered from the reference sites were low (2-3 ng) in comparison to the Columbus, Grand Island, and Hastings WWTP sites suggesting that the WWTP sites were impacted by municipal wastewater sources.

The presence of estrogens downstream of the Hastings and Grand Island WWTPs is not surprising. Several studies have detected estrogenic compounds in WWTP effluent and in receiving waters (Williams et al., 2003; Aerni et al., 2004; Lee and Rasmussen, 2006). However, it is somewhat unclear why receiving waters downstream of some WWTPs contained detectable levels of estrogens, while others did not. In this study, relatively large amounts of estrogens were recovered in POCIS downstream of the Grand Island and Hastings WWTPs, but not downstream of the Columbus WWTP. While the cause of this difference is difficult to determine ex post facto, the treatment processes employed by the WWTPs in this study may account for some of these differences. The secondary treatment process employed by the Columbus and Grand Island WWTPs is activated sludge, whereas, the treatment process employed by the Hastings WWTP is a trickling filter. Trickling filters have been shown to be less effective at removing estrogens than activated sludge treatment (Svenson et al., 2003; Servos et al., 2005; Lee and Rasmussen, 2006), which may explain why a greater quantity of estrogens were detected in POCIS extracts from Hastings than Columbus. The POCIS extracts from Grand Island had an estrogenic equivalency 10 times higher than that of POCIS from Columbus. It is therefore possible that retention time and other conditions specific to the Grand Island WWTP reduce the efficiency of estrogen removal relative to that observed at the Columbus WWTP.

The high levels of $E_{1}$ and $E_{2}$ recovered from the Hastings WWTP discharge relative to the other locations may, in part, be due to the fact that all of the water in the receiving stream originates from the WWTP. It is possible that a lack of dilution contributes to elevated levels of estrogens at this location.

Qualitatively, the estrogen metabolites found downstream from the Nebraska WWTPs are consistent with those documented downstream from other WWTPs. For example, $E_{1}$ and $E_{2}$ were detected downstream of the Grand Island and Hastings WWTPs, whereas $\mathrm{E}_{3}$ and $\mathrm{EE}_{2}$ were not. This finding is consistent with the results from several other studies, as $\mathrm{E}_{1}$ and $\mathrm{E}_{2}$ are commonly detected downstream of WWTPs (Williams et al., 2003; Vermeirssen et al., 2005). Furthermore, $\mathrm{E}_{3}$ and $\mathrm{EE}_{2}$ are rarely detected in effluent samples (Rodgers-Gray et al., 2001; Todorov et al., 2002; Huggett et al., 2003) or in water samples collected downstream of WWTPs (Williams et al., 2003; Vermeirssen et al., 2005).

\section{Gene Expression}

The males deployed downstream from the Hastings WWTP, in contrast to all of the other caged males in this study, had elevated vg1 and ERa mRNA expression (Figure 2). Clearly, these males had been feminized. Furthermore, immature females deployed at this site had similar hepatic vg1 mRNA expression patterns as the males. This demonstrates the utility of immature fathead minnow females as sentinel organisms for the detection of exogenous estrogens. However, maturation status has been implicated previously (Burki et al., 2006) as a confounding factor with respect to female vg expression; therefore, caution is warranted regarding the use of female fish in this capacity.

While vg1 induction (as measured by mRNA expression or serum protein concentrations) is the most widely used biomarker of exposures to estrogenic compounds in fish, the current study provides evidence suggesting that hepatic ERa mRNA expression may also serve as a biomarker of estrogen exposures. The use of ER expression as a biomarker of exposure to estrogens has also been proposed by Todorov et al. (2002).

\section{Polar Organic Chemical Integrative Samples and Gene Expression}

When considered together, the POCIS and hepatic gene expression data provide evidence regarding the occurrence and biological effect of estrogens that would not have been elucidated had either metric been used in isolation. Hepatic mRNA expression of the minnows deployed at the three reference sites and upstream and downstream from the Columbus WWTP were all uniformly low. This result was expected, as the POCIS de- 
ployed at each of these sites contained very low levels of estrogens. Hepatic gene expression of the minnows deployed upstream and downstream of the Grand Island WWTP were also uniformly low, despite the fact that the estrogen equivalent mass detected in POCIS deployed at the downstream site was approximately 10 times greater than that of POCIS deployed at the upstream and reference locations. This result suggests that the concentration of estrogens in the water downstream from the Grand Island WWTP was not sufficiently large enough to evoke the expression of estrogen-responsive genes. The minnows deployed downstream from the Hastings WWTP experienced a dramatic increase in the expression of the two estrogen-responsive genes measured. This finding corroborates with the POCIS data, which indicate that this site had the greatest quantity of estrogens relative to the other sampled sites.

\section{Acknowledgments}

The authors acknowledge financial support for this project from the Nebraska Department of Environmental Quality, the Nebraska Water Center, and the University of Nebraska-Omaha, College of Arts and Sciences. Molly Hartmann, Sarah Gustafson, and Teyona Damon provided technical support for the project. The authors also gratefully acknowledge the cooperation of the Columbus, Grand Island, and Hasting WWTP operators.

\section{Literature Cited}

Aerni, H.R., B. Kobler, B.V. Rutishauser, F.E. Wettstein, R. Rischer, W. Giger, A. Hungerbuhler, M.D. Marazuela, A. Peter, R. Schonenberger, A.C. Vogeli, M.J.F. Suter, and R.I.L. Eggen, 2004. Combined Biological and Chemical Assessment of Estrogenic Activities in Wastewater Treatment Plant Effluents. Analytical and Bioanalytical Chemistry 378:688-696.

Alvarez, D.A., J.D. Petty, J.N. Huckins, T.L. Jones-Lepp, D.T. Getting, J.P. Goddard, and S.E. Manahan, 2004. Development of a Passive, In Situ, Integrative Sampler for Hydrophilic Organic Contaminants in Aquatic Environments. Environmental Toxicology and Chemistry 23(7):1640-1648.

Alvarez, D.A., P.E. Stackelberg, J.D. Petty, J.N. Huckins, E.T. Furlong, S.D. Zaugg, and M.T. Meyer, 2005. Comparison of a Novel Passive Sampler to Standard Water-Column Sampling for Organic Contaminants Associated With Wastewater Effluents Entering a New Jersey Stream. Chemosphere 61:610-622.

Balch, G.C., K. Shami, P.J. Wilson, Y. Wakamatsu, and C.D. Metcalfe, 2004. Feminization of Female Leukophore-Free
Strain of Japanese Medaka (Oryzias latipes) Exposed to $17 \beta$-Estradiol. Environmental Toxicology and Chemistry 23:2763-2768.

Baronti, C., R. Curini, G. D’Ascenzo, A. Di Corcia, A. Gentili, and R. Samperi, 2000. Monitoring Natural and Synthetic Estrogens at Activated Sludge Sewage Treatment Plants and in a Receiving River Water. Environmental Science and Technology 34(24):5059-5066.

Brion, F., C.R. Tyler, X. Palazzi, B. Laillet, J.M. Porcher, J. Garric, and P. Flammarion, 2004. Impacts of $17 \beta$-Estradiol, Including Environmentally Relevant Concentrations, on Reproduction After Exposure During Embryo-Larval-, Juvenile- and Adult-Life Stages in Zebrafish (Danio rerio). Aquatic Toxicology 68:193-217.

Burki, R., E.L.M. Vermeirssen, O. Korner, C. Joris, P. BurkhardtHolm, and H. Segner, 2006. Assessment of Estrogenic Exposure in Brown Trout (Salmo trutta) in a Swiss Midland River: Integrated Analysis of Passive Samplers, Wild and Caged Fish, and Vitellogenin MRNA and Protein. Environmental Toxicology and Chemistry 25:2077-2086.

Carballa, M., F. Omil, J.M. Lema, M. Llompart, C. Garcia-Jares, I. Rodriguez, M. Gomez, and T. Ternes, 2004. Behavior of Pharmaceuticals, Cosmetics and Hormones in a Sewage Treatment Plant. Water Research 38:2918-2926.

Esperanza, V., G. Herry, F. Manciot, and J.M. Laine, 2006. Analysis of Estrogenic Hormones in Natural Waters, Wastewater and Sludge. Results From the First International Round Robin Test. Water Practice and Technology 1(2):1-8.

Gallassi, S., L. Viganò, and M. Sanna, 1996. Bioconcentration of Organochlorine Pesticides in Rainbow Trout Caged in the River Po. Chemosphere 32:1729-1739.

Goodbred, S.L., R.J. Gilliom, T.S. Gross, N.P. Denslow, W.L. Bryant, and T.R. Schoeb, 1997. Reconnaissance of 17b-Estradiol, 11-Ketotestosterone, Vitellogenin, and Gonad Histopathology in Common Carp of United States Streams Potential for Contaminant-Induced Endocrine Disruption. United States Geological Survey Open-File Report 96-627, 47 pp.

Hartley, W.R., A. Thiyagarajah, M.B. Anderson, M.W. Broxson, S.E. Major, and S.I. Zell, 1998. Gonadal Development in Japanese Medaka (Oryzias latipes) Exposed to 17 $\beta$-Estradiol. Marine Environmental Research 46:145-148.

Hirai, N., A. Nanba, M. Koshio, T. Kondo, M. Mortia, and N. Tatarazako, 2006. Feminization of Japanese Medaka (Oryzias latipes) Exposed to 17beta-Estradiol: Formation of Testis-Ova and Sex-Transformation During Early-Ontogeny. Aquatic Toxicology 77:78-86.

Holbech, H., K. Kinnberg, G.I. Petersen, P. Jackson, K. Hylland, L. Norrgren, and P. Bjerregaard, 2006. Detection of Endocrine Disrupters: Evaluation of a Fish Sexual Development Test (FSDT). Comparative Biochemistry and Physiology 144C:57-66.

Hu, J., H. Zhang, and H. Chang, 2005. Improved Method for Analyzing Estrogens in Water by Liquid ChromatographyElectrospary Mass Spectrometry. Journal of Chromatography. A, 1070(1-2):221-224.

Huggett, D.B., C.M. Foran, B.W. Brooks, J. Weston, B. Peterson, 
K.E. Marsh, T.W. La Point, and D. Schlenk, 2003. Comparison of In Vitro and In Vivo Bioassays for Estrogenicity in Effluent From North American Municipal Wastewater Facilities. Toxicological Sciences 72:77-83.

Imai, S., J. Koyama, and K. Fujii, 2005. Effects of 17 $\beta$-Estradiol on the Reproduction of Java-Medaka (Oryzias javanicus), a New Test Fish Species. Marine Pollution Bulletin 51:708-714.

Ingrand, V., G. Herry, J. Beausse, and M.-R. de Roubin, 2003. Analysis of Steroid Hormones in Effluents of Wastewater Treatment Plants by Liquid Chromatography-Tandem Mass Spectrometry. Journal of Chromatography. A 1020(1):99-104.

Johnson, A.C. and J.P. Sumpter, 2001. Removal of Endocrine-Disrupting Chemicals in Activated Sludge Treatment Works. Environmental Science and Technology 35(24):4697-4703.

Kolok, A.S., D.D. Snow, S. Kohno, M.K. Sellin, and L.J. Guillette, Jr, 2007. Occurrence and Biological Effect of Exogenous Steroids in the Elkhorn River, Nebraska, USA. Science of the Total Environment 388:104-115.

Kolpin, D.W., E.T. Furlong, M.T. Meyer, E.M. Thurman, S.D. Zaugg, L.B. Barber, and H.T. Buxton, 2002. Pharmaceuticals, Hormones, and Other Organic Wastewater Contaminants in U.S. Streams, 1999-2000: A National Reconnaissance. Environmental Science and Technology 36(6):1202-1211.

Kramer, V.J., S. Miles-Richardson, S.L. Pierens, and J.P. Giesy, 1998. Reproductive Impairment and Induction of AlkalineLabile Phosphate, a Biomarker of Estrogen Exposure, in Fathead Minnows (Pimephales Promelas) Exposed to Waterborne 17 $\beta$-Estradiol. Aquatic Toxicology 40:335-360.

Lee, C.J. and T.J. Rasmussen, 2006. Occurrence of Organic Wastewater Compounds in Effluent-Dominated Streams in Northeastern Kansas. Science of the Total Environment 371:258-269.

Matthiessen, P., D. Arnold, A.C. Johnson, T.J. Pepper, T.G. Pottinger, and K.G.T. Pulman, 2006. Contamination of Headwater Streams in the United Kingdom by Oestrogenic Hormones From Livestock Farms. Science of the Total Environment 367:616-630.

Otto, D.M.E., J.K. Buttner, D.M. Arquette, and T.W. Moon, 1996. Impaired Inducibility of Xenobiotic and Antioxidant Responses in Rainbow Trout Exposed to Polychlorinated Biphenyl Contaminated Sediments in the St. Lawrence River. Chemosphere 33:2021-2032.

Panter, G.H., R.S. Thompson, and J.P. Sumpter, 1998. Adverse Reproductive Effects in Male Fathead Minnows (Pimephales promelas) Exposed to Environmentally Relevant Concentrations of the Natural Oestrogens, Oestradiol and Oestrone. Aquatic Toxicology 42:243-253.

Petty, J.D., J.N. Huckins, D.A. Alvarez, W.G. Brumbaugh, W.L. Cranor, R.W. Gale, A.C. Rastall, T.L. Jones-Lepp, T.J. Leiker, C.E. Rostad, and E.T. Furlon, 2004. A Holistic Passive Integrative Sampling Approach for Assessing the Presence and Potential Impacts of Waterborne Environmental Contaminants. Chemosphere 54:695-705.
Roberts, A.P., J.T. Oris, G.A. Burton, Jr., and W.H. Clements, 2005. Gene Expression in Caged Fish as a Fish-Tier Indicator of Contaminant Exposure in Streams. Environmental Toxicology and Chemistry 24:3092-3098.

Rodgers-Gray, T.P., S. Jobling, C. Kelly, S. Morris, G. Brighty, M.J. Waldock, J.P. Sumpter, and C.R. Tyler, 2001. Exposure of Juvenile Roach (Rutilus rutilus) to Treated Sewage Effluent Induces Dose-Dependent and Persistent Disruption in Gonadal Duct Development. Environmental Science and Technology 35:462-470.

Servos, M.R., D.T. Bennie, B.K. Burnison, A. Jurkovic, R. McInnis, T. Neheli, A. Schnell, P. Seto, S.A. Smyth, and T.A. Ternes, 2005. Distribution of Estrogens, 17 $\beta$-Estradiol and Estrone, in Canadian Municipal Wastewater Treatment Plants. Science of the Total Environment 336:155-170.

Sheahan, D.A., G.C. Brighty, M. Daniel, S.J. Kirby, M.R. Hurst, J. Kennedy, S. Morris, E.J. Routledge, J.P. Sumpter, and M.J. Waldock, 2002. Estrogenic Activity Measured in a Sewage Treatment Works Treating Industrial Inputs Containing High Concentrations of Alkylphenolic Compounds - A Case Study. Environmental Toxicology and Chemistry 21:507-514.

Shioda, T. and M. Wakabayashi, 2000. Effect of Certain Chemicals on the Reproduction of Medaka (Oryzias latipes). Chemosphere 40:239-243.

Soto, A.M., J.M. Calabro, N.V. Prechtl, A.Y. Yau, E.F. Orlando, A. Daxenberger, A.S. Kolok, L.J. Guillette, Jr., B. le Bizec, I.G. Lange, and C. Sonnenschein, 2004. Androgenic and Estrogenic Activity in Cattle Feedlot Effluent Receiving Water Bodies of Eastern Nebraska, USA. Environmental Health Perspectives 112:346-352.

Svenson, A., A.S. Allard, and M. Ek, 2003. Removal of Estrogenicity in Swedish Municipal Sewage Treatment Plants. Water Research 37:4433-4443.

Todorov, J.R., A.A. Elskus, D. Schlenk, P.L. Ferguson, B.J. Brownawell, and A.E. McElroy, 2002. Estrogenic Responses of Larval Sunshine Bass (Morone saxatilis $\times$ M. chrysops) Exposed to New York City Sewage Effluent. Marine Environmental Research 54:691-695.

Vermeirssen, E.L., O. Korner, R. Schonenberger, M.J.F. Suter, and P. Burkhardt-Holm, 2005. Characterization of Environmental Estrogens in River Water Using a Three Pronged Approach: Active and Passive Water Sampling and the Analysis of Accumulated Estrogens in the Bile of Caged Fish. Environmental Science and Technology 39(21):8191-8198.

Williams, R.J., A.C. Johnson, J.J.L. Smith, and R. Kanda, 2003. Steroid Estrogens Profiles Along River Stretches Arising From Sewage Treatment Works Discharges. Environmental Science and Technology 37(9):1744-1750.

Yamamoto, A., N. Kakutani, K. Yamamoto, T. Kamiura, and H. Miyakoda, 2006. Steroid Hormone Profiles of Urban and Tidal Rivers Using LC/MS/MS Equipped With Electrospray Ionization and Atmospheric Pressure Photoionization Sources. Environmental Science and Technology 40(13):4132-4137. 